\title{
TEXAS PRISONERS' REFLECTIONS ON REIURNING HOME
}

\section{KEY FINDINGS}

- Most Texas prisoners in the study had extensive criminal histories, with 63 percent having been convicted more than once in the past and 35 percent serving time for a parole or probation violation.

- Many prisoners had significant educational and employment deficits: 45 percent did not have a high school degree or equivalent upon entering prison or state jail and over half had been fired from a job in the past. Despite these deficiencies, at least 9 percent obtained their GED during incarceration and 15 percent had a job lined up for after their release.

- Eighty percent of prisoners reported illegal drug use prior to their incarceration (mostly cocaine and marijuana), yet only 21 percent participated in a specific drug or alcohol treatment program while incarcerated. ${ }^{3}$

(Continued on page 2)

\section{OCTOBER 2005}

NANCY G. LA VIGNE VERA KACHNOWSKI

URBAN INSTITUTE

2100 M STREET, N.W. WASHINGTON, D.C. 20037 n 2002, the Texas Department of Criminal Justice released 58,949 people from prisons and state jails across the state, nearly six times the number of prisoners released in 1980. ${ }^{1}$ Texas alone, with one of the largest prison populations in the country, accounts for almost 10 percent of all prisoners released from state and federal prisons nationwide each year. ${ }^{2}$ The sheer number of prisoners released annually, along with a growing appreciation for the substantial challenges that ex-prisoners face as they reenter society, has brought prisoner reentry — both in Texas and nationwide - to the forefront of the public agenda.

To help inform the next generation of reentry policy and practice, the Urban Institute launched Returning Home: Understanding the Challenges of Prisoner Reentry, a multistate research project in Maryland, Illinois, Ohio, and Texas. The purpose of Returning Home is to develop a deeper understanding of the reentry experiences of returning prisoners, their families, and their communities. This research project involves interviews with prisoners before and after their release from state correctional facilities, interviews with ex-prisoners' family members, focus groups with residents in neighborhoods to which many prisoners return, and interviews with community stakeholders. State laws and policies are also reviewed to provide overall policy context. (For more details on the study methodology, see page 11.)

This report presents findings from surveys completed by 676 prisoners shortly before their release from Texas prisons and state jails and their return to the Houston area. We present descriptive statistics on respondents' criminal, substance abuse, and employment histories; current health problems; in-prison programming experiences; relationships with family members; and expectations for release. Differences among respondents based on gender and type of confinement (i.e., prison or state jail) are highlighted in sidebars. Overall, these findings describe a population with extensive histories of substance use and criminal behavior, yet strong family ties and great optimism for what life will be like on the outside.

\section{PRELIMINARY FINDINGS IN TEXAS}

These preliminary findings represent the views and experiences of 676 Texas prison and state jail releases - 414 men and 262 women. With regard to the 


\section{KEY FINDINGS}

(Continued from page 1)

- Female prisoners had more serious histories of drug use than male prisoners, but were less likely to have received substance abuse treatment.

- Prisoners had positive views of their health, with 79 percent rating it as "good" or "excellent," yet notable shares reported having been diagnosed with chronic or infectious diseases, as well as depression or other mental illnesses.

- State jail confinees had lower levels of self-esteem and control over their lives than state prisoners and were less likely to have supportive family relationships.

- Family was the greatest anticipated source of financial resources, housing, and emotional support after release. Expectations for family reunification were high; 80 percent believed it would be easy to renew relationships with their children.

demographic characteristics of our sample, 58 percent of the respondents were black, 26 percent were white, and 16 percent were from other racial groups. Sixteen per- cent of the sample was Hispanic or Latino/Latina (of any race). The average age at the time of the prerelease interview was 36 years old.

\section{CRIMINAL JUSTICE HISTORY}

Most respondents reported having long histories of involvement with the criminal justice system. ${ }^{4}$ More than half ( 53 percent) were first arrested at age 18 or younger and one-quarter had served time in a juvenile facility. As adults, 81 percent had been convicted more than once, 63 percent had been in prison or state jail at least once before, and 56 percent had their parole or probation revoked at least once. Regarding their current prison or state jail terms, over half of the sample (52 percent) was convicted of drug offenses-37 percent for drug possession and 15 percent for drug dealing (figure 1). Twenty-four percent were convicted for property crimes, ${ }^{5} 9$ percent for violent offenses, and the remaining 15 percent for other offenses. Fortythree percent of respondents had been serving time in prison or state jail because of a parole or probation violation, with 19 percent returned for technical violations and 24 percent returned for new crimes

Figure 1. Distribution of Study Sample by Self-Reported Conviction Offense ( $\mathrm{N}=674$ )

Drug possession

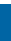

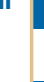

Property

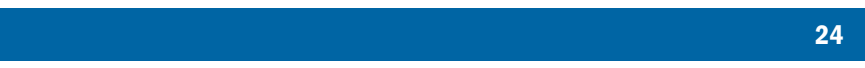

Other

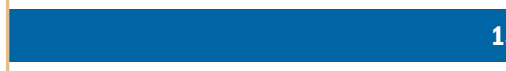

Drug sale

15

Violent

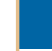

15 
committed while on probation or parole. The average length of incarceration was about 24 months, with 76 percent of respondents serving two years or less. A very small share of respondents (4 percent) reported involvement with a gang prior to their prison term; of these, 70 percent were in a gang for more than three years.

\section{EDUCATION}

Most respondents had significant educational, vocational, and employment needs. Forty-five percent did not possess a high school degree or equivalent when they entered prison. During their prison stay, however, the percentage of prisoners reporting the equivalent of a high school education or higher increased from 55 to 64 percent. In addition, respondents expressed an interest in furthering their education, with three-quarters reporting that they wanted to take classes or training after their release.

\section{EMPLOYMENT}

Texas prisoners preparing for release also had significant employment deficits. While two-thirds reported legal employment at one or more jobs in the six months prior to incarceration, 56 percent reported that at least some of their income during that time came from illegal activity, and 21 percent indicated most or all of their income was illegal. Only half of the sample (51 percent) had ever held a job for two years or more, and roughly the same share (53 percent) had been fired from a job at least once before. Once incarcerated, 61 percent of the sample worked at some point while in prison or state jail; the most common job types were kitchen or dietary (27 percent), sanitation or maintenance (21 percent), and clerk positions (10 percent).

Almost all respondents (93 percent) felt that finding a job after release was important. At the same time, most respondents who did not already have jobs lined up (87 percent) thought they would need some help or a lot of help in finding a job (figure 2). Of respondents who

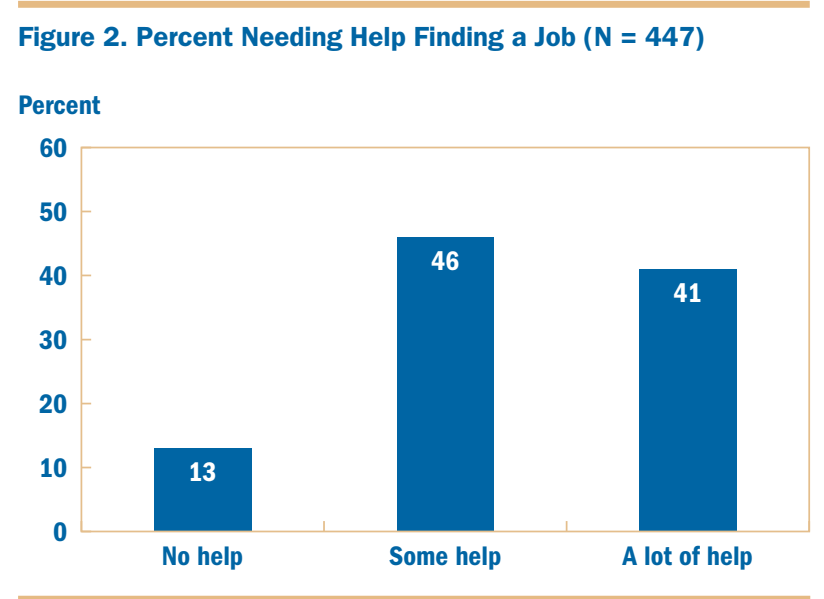

Note: Data are from respondents who did not already have jobs lined up.

wanted job training after release, 84 percent wanted some help or a lot of help in getting it (figure 3). Only 15 percent of respondents reported that they already had a job lined up on the outside. Of those who did not have a job lined up at the time of the interview, most planned on using newspaper ads to find employment (70 percent), followed by walking in and applying (62 percent), talking to friends (58 percent), answering

Figure 3. Percent Needing Help Getting Job Training $(N=560)$

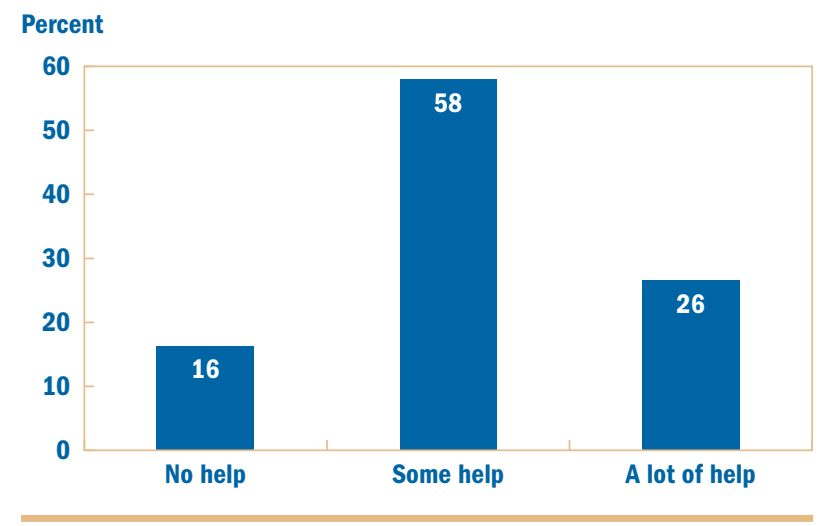

Note: Data are from respondents who wanted job training. 


\section{REENTRY DEFINED}

This report defines "reentry" as the process of leaving an adult correctional institution and returning to society. We have limited our scope to those sentenced to serve time in state correctional institutions to focus on individuals who are convicted of more serious offenses, are eligible for state correctional programs, and may be managed by state correctional, parole, and felony probation systems after release. Unlike other states, Texas has two categories of state correctional units that incarcerate felons and misdemeanants: state jails, which house individuals sentenced to less than two years for a nonviolent Class A misde- meanor, a third-degree felony, or a probation revocation; and state prisons, which house individuals sentenced to two years or more for higher-level felony offenses. Texas criminal justice officials refer to those prisoners confined in state jails as "confinees"; we reference them as such in this report only when distinguishing this group from those incarcerated in state prisons. While the two populations may require different reentry programs and policies, the vast majority of both prisoners and state jail confinees return to the community following state custody, and therefore both groups must be considered when examining the reentry experience in Texas. help wanted signs (54 percent), and talking to relatives (54 percent).

\section{FINANCIAL SUPPORT}

Respondents indicated they would have few financial resources with which to support themselves upon release. With the exception of those who already had jobs waiting for them, respondents expected to be dependent on family, friends, and public assistance. Indeed, family (54 percent) was the most frequently reported source of expected financial support after release, with fewer respondents expecting support from their own jobs (40 percent), friends (24 percent), public assistance (23 percent), or personal savings (14 percent). Fourteen percent of respondents did not expect to receive any financial support after release. Nonetheless, respondents were generally optimistic about their expected financial situations. Over two-thirds (71 percent) of respondents thought that it would be pretty easy or very easy to support themselves financially after release.

\section{SUBSTANCE USE}

Substance use was prevalent among this sample: eighty percent reported any drug use and 54 percent reported alcoholic intoxication in the six months prior to their current prison term. With regard to illegal drug use, the most commonly cited drugs were cocaine (57 percent) and marijuana (55 percent). In some cases, use of these drugs was extensive, with significant shares of respondents reporting daily cocaine (26 percent) or marijuana (20 percent) use in the six months prior to their incarceration. Heroin use, while prominent among other

Figure 4. Substance Use Treatment Participation $(\mathrm{N}=668)$

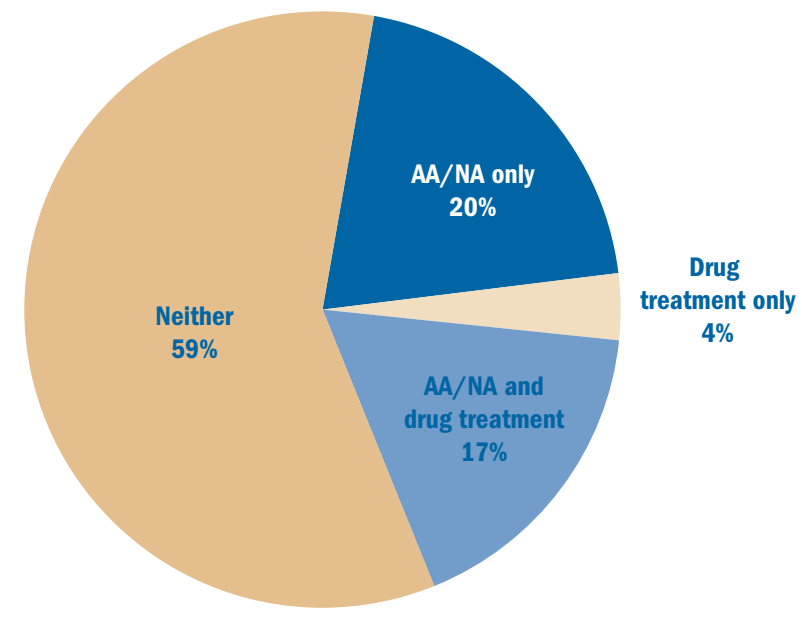

Note: AA/NA = Alcoholics Anonymous or Narcotics Anonymous. 
released prisoner populations, ${ }^{6}$ was not common among our sample; less than 5 percent reported any heroin use at all.

The widespread drug and alcohol use reported by respondents raises the question of how much access respondents had to in-prison substance abuse treatment programs. According to self-reports, 21 percent participated in a specific drug or alcohol treatment program, 37 percent attended Alcoholics Anonymous or Narcotics Anonymous (AA/NA), and 17 percent participated in both (figure 4). Despite this evidence of program participation, 19 percent of respondents reported they would likely use drugs after release if they knew they would not get caught, and 9 percent said they would do so even if they knew they would be arrested for it.

\section{HEALTH}

Respondents had positive views of their health -79 percent rated their overall health as good (45 percent) or excellent (34 percent). Despite these positive views, significant shares reported having been diagnosed with high blood pressure ( 35 percent), asthma ( 24 percent), arthritis (14 percent), or diabetes (10 percent). Infectious diseases were also prevalent, with prisoners indicating they had been previously diagnosed with Hepatitis B or C (21 percent), tuberculosis (8 percent), HIV or AIDS (7 percent), or another sexually transmitted disease

\section{INCARCERATION AND RELEASE TRENDS IN TEXAS}

Texas's incarceration and reentry trends are similar to those observed at the national level. Between 1980 and 2001, the total number of prisoners in Texas increased fivefold, from 28,543 to 151,003 prisoners. During this period, the per capita rate of imprisonment in Texas rose 248 percent (from 199 to 693 prisoners per 100,000 residents), mirroring the 242 percent increase in the U.S. imprisonment rate (from 139 to 476 prisoners per 100,000 residents). The growth in Texas's prison population is largely attributable to rising prison admissions and longer lengths of stay in prison. Admissions increased primarily due to an increase in arrests for violent and drug crimes, which resulted in a rise in the number of felony convictions. Prisoners spent more time in prison mainly because most received longer sentences and served longer portions of their sentences (i.e., time served). Falling parole approval rates and legislation requiring prisoners to serve greater percentages of their sentences both contributed to the increase in time served.

Texas's release patterns reflect these admissions and population trends: 58,949 prisoners were released from Texas Department of Criminal Justice (TDCJ) prisons and state jails in 2002 , nearly six times the number of prisoners released in 1980 (10,636). Government leaders, corrections officials, local organizations, and service providers are keenly aware of the reentry challenges in Texas, and they have begun to use both research and programmatic knowledge to address them. In July 2002, the TDCJ was awarded \$2 million from the U.S. Department of Justice, Office of Justice Programs, as part of the federal government's Serious and Violent Offender Reentry Initiative, which supports reentry initiatives nationwide. This grant provides the opportunity for Texas to continue to expand upon current reentry initiatives in the state. For example, a share of the funds will be used to develop reentry programs for administrative segregation prisoners, who currently have access to few or no programs, from three counties (Bexar, Dallas, and Harris). More recently, in the spring of 2004, TDCJ launched a planning process to create a Texas Reentry Programs Model, with the goal of successfully reintegrating all offenders under its supervision back into society with a system of programs. The reentry model programs will focus on education, employment, substance abuse, and sex offender treatment, with an emphasis on coordinating program delivery, sharing information, and assessing prisoners' needs across TDCJ divisions. 
(9 percent). In addition, 39 percent of respondents reported that they were currently on prescription medication for a health problem, with the majority being treated for diseases such as asthma and high blood pressure.

While physical health problems were prevalent among this population, mental health problems present an equally daunting challenge for prisoners preparing to return to Houston. Close to one in three respondents (30 percent) reported having been diagnosed with depression, and 16 percent reported having other mental health problems. Also of note is the intersection between substance use and health; 10 percent of respondents reported they had experienced health problems due to their drinking and 16 percent reported health problems due to drug use during the six months preceding their incarceration.

Despite these significant shares of respondents reporting physical and mental health conditions, the vast majority (90 percent) of respondents thought that it would be pretty easy or very easy for them to stay in good health after release. This finding runs counter to the almost three-quarters ( 73 percent) who reported they would need help getting health care after prison.

\section{FAMILY RELATIONSHIPS AND SUPPORT}

Family was a very important source of emotional support for prisoners during incarceration. Almost all respondents ( 93 percent) wanted their families to be involved in their lives during prison. Furthermore, 79 percent reported they felt close to their families during their prison stay, and, despite the limitations of confinement, 69 percent considered themselves to be a source of support for their families.

While measures of family support were high, so too were reports of family involvement with the criminal justice system. Two-thirds of respondents had at least one family member who had been convicted of a crime, and over a third ( 35 percent) had a family member currently in prison. Moreover, two-thirds reported that someone in their family had a history of problems with drugs or alcohol.

With regard to marital status, almost half (49 percent) had never been married, 22 percent reported being divorced or separated, and 21 percent were married or had been living with a partner as married prior to prison. The remainder described themselves as having been in and out of the same relationship ( 3 percent), were widowed ( 2 percent), or indicated some other type of relationship ( 3 percent). Many of these prisoners also left children behind: a little over half ( 54 percent) had children under 18 years old. Fifty-nine percent of respondents with minor children reported that they had lived with at least some of their children prior to prison, and 77 percent reported providing financial support to their children before prison.

Respondents had high expectations for renewing relationships with family members after their release; 79 percent believed it would be easy to do so. Eightytwo percent thought their families would be supportive after release; most (63 percent) expected to live with family after prison and 54 percent expected family to be a source of financial support (figure 5). Of respondents who were parents, 80 percent thought it would be easy to renew relationships with their children, and among those with minors, two-thirds expected at least some of these children would live with them after release.

\section{HOUSING AND COMIMNITY}

Perhaps in light of their high expectations of family support, most respondents in our sample did not expect that securing housing after their release would present difficulties. In the prerelease interview, 71 percent of respondents reported having housing lined up already, with most respondents (63 percent) expecting to live with a 
Figure 5. Expectations for Family Support after Release $(\mathrm{N}=661,666,661)$

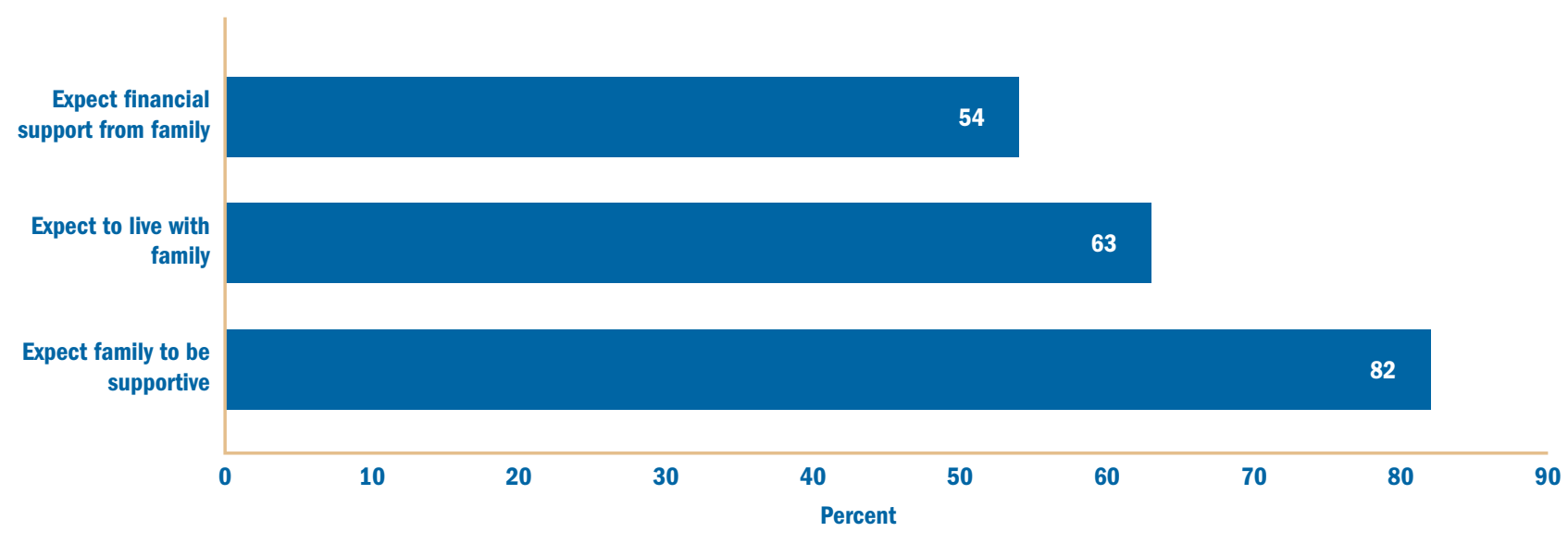

family member. Of the 29 percent who did not yet have housing arranged, the most common method for finding housing was to contact a family member (36 percent), followed by using a referral service or housing program (30 percent), asking a friend (23 percent), contacting a shelter (20 percent), using a government program (18 percent), checking the newspaper (18 percent), asking a spouse or partner (13 percent), and asking their parole officer (8 percent). Sixty-five percent of those prisoners who did not have housing lined up thought that it would be pretty easy or very easy to find a place to live, but a similar share (72 percent) also indicated they would need help doing so.

In terms of the neighborhoods where respondents expected to reside after their release, the majority ( 85 percent) believed that their postprison neighborhood would be a safe place to live and that it would not be difficult to stay out of trouble there (72 percent). While about one in five respondents ( 23 percent) said they were nervous about seeing certain people in their neighborhood following release, 58 percent indicated that they were looking forward to seeing certain people there. Expected civic participation after release was high, with 82 percent indicating that if they could vote after release, they would. ${ }^{7}$

\section{ATTITUDES AND BELIEFS}

Similar to Texas prisoners' views on family reunification, expectations for resolving challenges upon release were high. For example, respondents thought it would be easy to stay out of prison after release ( 84 percent) and to avoid a parole violation ( 81 percent of those who expected to be released on parole). Most also indicated that it would be unlikely or very unlikely for them to commit a crime ( 87 percent) or use drugs ( 81 percent) after release, even if they could do so without being caught. Despite these optimistic attitudes, at least two-thirds of the sample agreed that they would need help in dealing with various problems and challenges after release. Many prisoners wanted to improve their educational and vocational abilities, as indicated by the substantial percentages who expressed a need for help getting more education (73 percent) and job training (72 percent) after release. Also, nearly three-quarters (73 percent) wanted help obtaining financial assistance, transportation,

(Continued on page 10) 


\section{GENDER AND REENTRY}

Female and male respondents in our sample differed significantly on several dimensions (table 1). Female respondents entered prison or state jail with a greater number of children, on average, than men. Female respondents reported less family support both before and during prison and more negative family influences, such as family involvement with drug or alcohol use or the criminal justice system. Prior to their incarceration, female respondents were more likely to have used illegal drugs than male respondents, and 42 percent of women were using cocaine on a daily basis (versus 17 percent of men). In addition, more females than males reported being threatened, harassed, or hurt by family members prior to their incarceration.

Comparing criminal histories of male and female respondents reveals that males became involved with the criminal justice system at a younger age, on average, than females. With respect to their current incarcerations, more males were serving time for parole violations than females, and more females were serving time for probation violations than males. In addition, more females were convicted for drug crimes, prostitution, and fraud or forgery than their male counterparts (table 1).

During the time they spent in prison or state jail, a larger share of male respondents earned GEDs and participated in drug or alcohol treatment (excluding AA/NA) than female respondents. As is referenced in the State Jail versus State Prison Respondents sidebar (on page 9), some gender differences may be explained by the fact that much higher shares of female respondents were in state jails (49 percent) than prisons (25 percent).

Although both male and female respondents reported their health at the time of the prerelease interview as being good overall, males and females reported suffering from different ailments. Notably, the shares of females reporting depression, asthma, and STDs other then HIV were roughly double the shares of male respondents reporting these conditions. At the prerelease interview, females reported higher levels of spirituality, and larger shares of female respondents than male respondents reported praying or meditating and reading religious literature on a daily basis.

More males than females expected to live with family after release, with more than one-third (38 percent) of male respondents expecting to live with their mothers

(Continued on page 9)
Table 1. Significant Differences between Male and Female Respondents

Female Male

\section{Before prison}

Number of children

Ever threatened, harassed, or hurt by family

$27 \% \quad 9 \%$

Ever threatened, hurt, or harassed family

Worked before prison

$7 \% \quad 13 \%$

Any illegal drug use before prison

$55 \% \quad 75 \%$

$84 \% \quad 78 \%$

\section{Criminal justice history}

Age at first arrest

23

20

Served time in juvenile correctional facility

Currently serving time for parole violation

$18 \%$

Currently serving time for probation violation

$20 \%$

Parole or probation violation for a new crime

\section{In-prison experiences}

Earned a GED while incarcerated

Participated in drug or alcohol treatment

Ever diagnosed with depression

$14 \%$

$40 \%$

$25 \%$

Ever diagnosed with asthma

$32 \% \quad 17 \%$

Ever diagnosed with STDs, not HIV

$14 \% \quad 5 \%$

Prayed or meditated daily

$76 \% \quad 60 \%$

Read Bible or other religious literature daily

$54 \%$

$39 \%$

\section{Expectations}

Expected post-prison earnings

Expect to live with family after release

$\$ 8 / \mathrm{hr} \$ 11 / \mathrm{hr}$

Need help finding a job after release

$56 \% \quad 67 \%$

$66 \% \quad 55 \%$

Need help getting more education $\quad 77 \% \quad 71 \%$

Need help getting job training $\quad 76 \% \quad 69 \%$

Need help getting child care $\quad 33 \% \quad 22 \%$

Need help getting counseling $\quad 59 \% \quad 45 \%$

Need help getting financial assistance $\quad 80 \% \quad 69 \%$

Need help getting mental health care $\quad 42 \% \quad 26 \%$

Need help getting drug or alcohol

treatment

$48 \% \quad 32 \%$

Note: These differences are statistically significant at $p \leq .05$. 


\section{GENDER AND REENTRY (Continued)}

after incarceration (versus 27 percent of females). Male and female respondents generally had similar expectations about how easy or hard it would be to surmount reentry challenges, such as finding and keeping jobs and finding a place to live. However, larger percentages of female than male respondents reported wanting some help or a lot of help to find a job and to get more education, job training, counseling, financial support, mental health treatment, and drug or alcohol treatment after release.

\section{STATE JAIL VERSUS STATE PRISON RESPONDENTS}

State jail respondents differed quite a bit from state prison respondents both with regard to their criminal justice histories and family relationships as well as their experiences during incarceration (table 2). Most notably, state prisoners in our sample were more likely to be male ( 75 percent) than were confinees (51 percent). Given this gender bias, determining the extent to which gender rather than type of facility explains the differences between state prisoners and confinees is difficult (for more on gender differences between respondents, see the Gender and Reentry sidebar on page 8).

Many differences between state prisoner and confinee respondents are a function of the nature of the facility, with state jails more likely to house low-level drug offenders and less likely to offer programming. Thus, state prisoners were more likely to have improved their educational level, to have participated in training programs, and to have received alcohol or drug abuse treatment during their incarceration.

Overall, state jail confinees had lower levels of selfesteem and lower perceptions of control over their lives $^{8}$ than state prisoner respondents. They also had lower levels of family support and rated the quality of their relationships with family members lower than state prisoners did.

With regard to similarities between the two groups, state prisoners had roughly the same age, racial composition, and education levels as state jail confinees. Both groups reported praying and reading religious literature at roughly equal frequencies and reported relatively similar levels of need for help after release.
Table 2. Significant Differences between State Jail and State Prison Respondents

\section{State jail State prison}

\section{Before prison}

Ever threatened, harassed, or

hurt by family

Ever threatened, hurt, or harassed family

$9 \% \quad 12 \%$

Worked before prison

$61 \%$

$75 \%$

Any illegal drug use before

prison

$84 \%$

$75 \%$

\section{Criminal justice history}

Age at first arrest

22

Served time in juvenile correctional facility

$22 \%$

$29 \%$

Currently serving time for parole

violation

$2 \%$

Currently serving time for

probation violation

$20 \%$

\section{In-prison experiences}

Earned a GED while

incarcerated

$8 \% \quad 15 \%$

Participated in drug or alcohol treatment

$10 \%$

Ever diagnosed with depression

$34 \%$

$24 \%$

Ever diagnosed with asthma

$27 \%$

$20 \%$

Ever diagnosed with STDs, not HIV

\section{Expectations}

Expected postprison earnings

Expect to live with family after release

$\$ 10 / h r \quad \$ 11 / h r$

$59 \%$

$79 \%$

Need help getting mental health care

$36 \%$

Note: These differences are statistically significant at $p \leq .05$. 
or health care after release, and notable percentages wanted help getting counseling (51 percent) and mental health treatment (32 percent) as well.

We also asked a number of questions regarding respondents' self-esteem, control over life, and spiritual beliefs. ${ }^{9}$ Just over half ( 53 percent) of the sample showed high levels of self-esteem prior to release, and two-thirds (62 percent) had strong feelings of control over their lives. ${ }^{10}$ Seventy-three percent thought it would be easy to achieve social acceptance after release. Respondents also appeared to be very spiritual, with 80 percent showing high levels of faith or religious practices. Many reported praying or meditating daily (66 percent) or reading the Bible, Koran, or other religious literature daily (45 percent).

\section{POSTRELEASE SUPERVISION}

Forty-one percent of the study sample indicated they would be subject to postrelease supervision, ${ }^{11}$ a somewhat smaller share than the 55 percent of all prisoners released from Texas in 2002. ${ }^{12}$ The share of those who expect to be released to supervision is dramatically different for state prisoners compared with state jail confinees, with 92 percent of state prisoners indicating they would be on supervision versus just 5 percent of jail confinees. Of those who knew they would be under parole supervision, 87 percent expected their parole officer to be helpful with their transition back to the community. Moreover, 81 percent of those who expected to be on parole thought that it would be pretty easy or very easy to avoid a parole violation.

\section{LOOKING FORWARD}

This research brief is the first in a series of planned publications on findings from our original data collection in Texas. We will also be developing topic-specific research summaries to inform policy and practice about prisoner reentry and will produce a full technical report, including analyses of all pre- and postrelease data from prisoners and their families, postrelease criminal history data, and findings from the interviews with community lead- ers and focus groups with community residents. This final report will present the conclusions from the study and discuss policy implications. The results of the Texas study will also be a part of a larger cross-state analysis based on Returning Home research conducted in Maryland, Illinois, and Ohio.

\section{ENDNOTES}

${ }^{1}$ For a detailed description of prisoner reentry in Texas, please refer to Jamie Watson, Amy L. Solomon, Nancy G. La Vigne, and Jeremy Travis. 2004. "A Portrait of Prisoner Reentry in Texas." Washington, DC: The Urban Institute.

${ }^{2}$ This statistic is based on a Bureau of Justice Statistics estimate that 630,000 prisoners were released from federal and state prisoners in 2002. Paige M. Harrison and Jennifer C. Karberg. 2003. “Prison and Jail Prisoners at Midyear 2002.” Washington, DC: U.S. Department of Justice, Bureau of Justice Statistics.

${ }^{3}$ Aside from Alcoholics Anonymous (AA) or Narcotics Anonymous (NA), which 37 percent of respondents attended.

${ }^{4}$ The information in this section is based upon self-reported criminal behavior and may differ from TDCJ records. A comparison of self-reported and official data for 624 respondents for whom official records were available suggested that respondents may have underreported drug possession (33 versus 39 percent) and violent crime ( 9 versus 11 percent) as their current conviction offense, and overreported being a parole or probation violator (37 versus 19 percent).

${ }^{5}$ For this policy brief, property crimes consist of burglary, theft (including auto theft), and fraud or forgery.

${ }^{6}$ Findings from the Returning Home study in Maryland indicated that 41 percent of male and female prisoners returning to Baltimore had used heroin on a daily basis in the six months leading up to their most recent incarceration. Christy Visher, Vera Kachnowski, Nancy G. La Vigne, and Jeremy Travis. 2004. "Baltimore Prisoners' Experiences Returning Home.” Washington, DC: The Urban Institute.

${ }^{7}$ Texas law bars all incarcerated persons and those on probation and parole from voting. Effective in 1998, however, Texas removed its two-year waiting period after completion of sentence for the restoration of voting rights. Christopher Uggen and Jeffrey Manza. 


\section{RETURNING HOME STUDY DESIGN AND METHODOLOGY}

The Returning Home study is being conducted in four states under the direction of principal investigator Christy Visher. Based on a number of criteria, including quality and availability of data, and variation in sentencing and release practices, we selected Maryland for a pilot study and Illinois, Ohio, and Texas as the states in which the full research study would be conducted. The project is being carried out in close collaboration with corrections officials, policymakers, researchers, and community leaders in each state. Data collection has already been completed in Maryland and Illinois and is currently under way in Ohio and Texas.

In Texas, the study design involves three separate data collection efforts with prisoners returning to the Houston area: (1) a self-administered survey given to groups of prisoners in the week prior to their release; (2) a one-on-one interview with sample members two to five months after release; and (3) a one-on-one interview at 9 to 12 months after release. Our goal is to capture each respondent's life circumstances immediately prior to and following their release from prison, as well as about a year after their return to the community. Thus, the surveys and interviews explore various reentry expectations, needs, and experiences, such as those related to prerelease preparation, postrelease housing and employment, and the renewal of personal relationships.

Participants were recruited over a seven-month period from the two state prisons to which all prisoners are transferred for processing before release, and two state jails that house a high number of confinees returning to the Houston area. In each facility, we scheduled times to explain the study and distribute a self-administered survey to those willing to participate. In several of the units, prisoners are convened in groups shortly prior to their release as part of a church-sponsored "Welcome Back" program that provides information on reentry resources. When possible, we took advantage of having the prisoners already gathered to present information about the study and to administer the survey before the "Welcome Back" program was presented. This strategy resulted in a participation rate of 88 percent and a resulting sample of 676 men and women. To assess how representative the sample is, we compared those in the prerelease sample for whom official records were available $(\mathrm{N}=624)$ with other 2004-2005 Texas releases in Harris County $(N=20,393)$, across a large number of factors. Only two differences emerged as statistically significant $(p<0.05)$ in a multivariate regression. Respondents in our sample were older (36 versus 34 years), and they were, by study design (since we intentionally oversampled female prisoners), less likely to be male (61 versus 83 percent).

In addition to interviews with ex-prisoners, we have conducted interviews with 427 family members nominated by our sample. These interviews, which are held two to four months after the prisoner's release, examine the impact of a returning prisoner on the family structure as well as the support that family members provide to exprisoners after release. We will also be holding focus groups with community residents in the Houston neighborhoods that receive the highest number of returning prisoners as well as conducting interviews with key community stakeholders.
2002. "Impact of Recent Legal Changes in Felon Voting Rights in Five States.” Briefing paper prepared for The National Symposium on Felony Disenfranchisement. Washington, D.C., September 30-October 1 .

8 "Control over life" was measured by nine items indicating whether respondents felt in control over things that happened to them or helpless in dealing with the problems of life.

${ }^{9} \mathrm{~A}$ full list of attitudinal scales, reliabilities, and the items that comprise them is available upon request. All scales achieved internal consistency reliabilities (Cronbach's alpha of .70 or above).
10 "Control over life" was measured by nine items indicating whether respondents felt in control over things that happened to them or helpless in dealing with the problems of life.

${ }^{11}$ An additional 3 percent of respondents were not sure whether or not they would be supervised.

${ }^{12}$ This could be explained by our sampling of prisoners returning specifically to the Houston area, in that a greater share of Houstonbound prisoners are released from state jails compared with those released from all over the state. 


\section{ACKNOWLEDGMENTS}

We would like to thank the many individuals and organizations that have contributed to the success of this research project. The Texas Department of Criminal Justice, especially Dimitria Pope, Janice Willett, and Rebecca Watts of the RED group and Captain Troy Selman, Warden Dennis Miller, Warden Detrah Lacy, and Warden Rebecca Adams were invaluable in facilitating access to the state prison and state jail units for interviews. We are particularly appreciative of the research and interview staff at NuStats, who skillfully conducted the original data collection for this report. We also thank the Urban Institute's Justice Policy Center staff who assisted in the production of this report, including Jennifer Castro, who helped prepare the data for this report, and Jenny Osborne and Christy Visher, for their review of earlier drafts of this document. The Returning Home study in Texas is funded by the generous support of the JEHT Foundation, the Rockefeller Foundation, the Robert Wood Johnson Foundation, and the Houston Endowment.

\section{FOR FURTHER READING}

Jamie Watson, Amy L. Solomon, Nancy G. La Vigne, and Jeremy Travis. 2004. "A Portrait of Prisoner Reentry in Texas." Washington, DC: The Urban Institute. http://www.urban.org/ url.cfm?ID=410972.

Nancy G. La Vigne, Christy Visher, and Jennifer Castro. 2004. “Chicago Prisoners' Experiences Returning Home.” Washington, DC: The Urban Institute. http://www.urban.org/ url.cfm?ID=311115.

Christy Visher, Vera Kachnowski, Nancy G. La Vigne, and Jeremy Travis. 2004. “Baltimore Prisoners' Experiences
Returning Home.” Washington, DC: The Urban Institute. http://www.urban.org/url.cfm?ID=310946.

Christy Visher, Nancy G. La Vigne, and Jill Farrell. 2003. "Illinois Prisoners' Reflections on Returning Home."

Washington, DC: The Urban Institute. http://www.urban. org/url.cfm?ID=310846.

Jeremy Travis, Amy L. Solomon, and Michelle Waul. 2001. "From Prison to Home: The Dimensions and Consequences of Prisoner Reentry." Washington, DC: The Urban Institute. http://www.urban.org/pdfs/from_prison_to_home.pdf.

To receive free monthly email updates on the research of the Justice Policy Center, join the Center's email distribution list by sending an email to JPC@ui.urban.org.

The views expressed are those of the authors and should not be attributed to the Urban Institute, its trustees, or its funders. 